\title{
Microbial Metabolism of Alicyclic Hydrocarbons: Isolation and Properties of a Cyclohexane-degrading Bacterium
}

\author{
By LYNNE A. STIRLING* AND R. J. WATKINSON \\ Shell Research Limited, Milstead Laboratory of Chemical Enzymology, Sittingbourne \\ Research Centre, Broad Oak Road, Sittingbourne, Kent, ME9 $8 A G$ \\ AND I. J. HIGGINS \\ *Biological Laboratory, University of Kent, Canterbury, Kent, CT2 $7 \mathrm{NJ}$
}

(Received 5 October 1976; revised 10 November 1976)

\begin{abstract}
SUMMARY
A micro-organism which grows on cyclohexane as sole carbon and energy source has been isolated from estuarine mud flats. It has been tentatively identified as a Nocardia. The organism, which is auxotrophic for biotin, grows on cyclohexane (supplied as a vapour) with a mean generation time of about $\mathrm{s} \mathrm{h}$ and a $Y_{\mathrm{sUB}}$ of $59.9 \mathrm{~g}$ dry wt (mol cyclohexane) ${ }^{-1}$. Growth on cyclohexane leads to the production of intracytoplasmic membrane structures which are not present after growth on succinate. Growth, respiration and enzyme studies are consistent with the degradation of cyclohexane via cyclohexanol, cyclohexanone, $\epsilon$-caprolactone and 6-hydroxycaproate. Extracts of organisms grown on cyclohexane contained cyclohexanol dehydrogenase, cyclohexanone monooxygenase and $\epsilon$-caprolactone hydrolase; these enzymes are absent from, or at very low activity in, extracts of organisms grown on succinate.
\end{abstract}

\section{INTRODUCTION}

Little is known about the microbial degradation of the alicyclic hydrocarbons cyclohexane and methylcyclohexane. They appear to be resistant to microbial attack and isolation of pure cultures able to utilize these substances is extremely difficult. Imelik (I948) described the isolation of a strain of Pseudomonas aeruginosa that grew on cyclohexane, but gave few experimental details, and growth of this bacterium on cyclohexane has not been further studied. More recently, a mixed bacterial culture from soil has been reported to grow on cyclohexane (Jones \& Edington, I968) whilst Tonge \& Higgins (1974) described an unidentified soil isolate and Nocardia petroleophila which grew on methylcyclohexane. Nocardia petroleophila probably catabolizes the hydrocarbon via 3-methylcyclohexanol and 3-methylcyclohexanone.

Cyclohexane co-oxidation was described by Beam \& Perry (1973) and a more detailed study by de Klerk \& van der Linden (1974) showed that it can be co-oxidized to cyclohexanol by a pseudomonad growing on heptane. Mixed cultures of this bacterium growing on heptane together with another pseudomonad isolate degraded cyclohexane completely. Methylcyclohexane can be co-oxidized to 4-methylcyclohexanone by a soil isolate growing on 2-methylbutane (Ooyama \& Foster, 1965).

In this paper we report the isolation and properties of a pure culture of a bacterium that grows on cyclohexane or methylcyclohexane. 


\section{METHODS}

Isolation, maintenance and culture of the micro-organism. The organism was isolated from estuarine mud flats near Sittingbourne, Kent, by classical enrichment techniques using methylcyclohexane vapour as sole carbon source. It was maintained on Lab-Lemco (Oxoid) agar slopes $(2 \cdot 3 \%, \mathrm{w} / \mathrm{v})$ and grown routinely at $30^{\circ} \mathrm{C}$ in a medium containing $\left(\mathrm{g}^{-1}\right)$ : $\mathrm{Na}_{2} \mathrm{HPO}_{4}, 4 \cdot 2 ; \mathrm{KH}_{2} \mathrm{PO}_{4}, 2 \cdot 8 ; \mathrm{MgSO}_{4} \cdot 7 \mathrm{H}_{2} \mathrm{O}, 0 \cdot 2 ; \mathrm{NH}_{4} \mathrm{NO}_{3}, 2 \cdot 0 ;$ plus I $\mathrm{ml}$ of trace element solution containing $\left(\mathrm{g} \mathrm{l}^{-1}\right): \mathrm{FeCl}_{3}, \mathrm{I}_{7} ; \mathrm{CaCl}_{2}, 0 \cdot 6 ; \mathrm{ZnSO}_{4}, 0 \cdot 2 ; \mathrm{CuSO}_{4} \cdot 7 \mathrm{H}_{2} \mathrm{O}, 0 \cdot 2 ; \mathrm{MnSO}_{4}$, $0.2 ; \mathrm{CoCl}_{2}, 0.8 ; \mathrm{H}_{3} \mathrm{BO}_{3}, 0 . \mathrm{I} ; \mathrm{Na}_{2} \mathrm{MoO}_{4} .2 \mathrm{H}_{2} \mathrm{O}, 0.3$. All the constituents were mixed and autoclaved at $\mathrm{I} 2 \mathrm{I}{ }^{\circ} \mathrm{C}$ for $\mathrm{I} 5 \mathrm{~min}$. In addition, autoclaved culture supernatant solutions $(4 \%, v / v)$ from exponential phase cultures of a succinate-grown pseudomonad isolate were added. For growth studies, hydrocarbons were supplied in the vapour phase from centrewell reservoirs (containing 5 to $10 \mathrm{ml}$ liquid substrate) in $250 \mathrm{ml}$ and 21 conical flasks containing 50 and $500 \mathrm{ml}$ medium respectively. Other growth substrates were dissolved in the minimal medium (I \%, w/v) and flasks were incubated on a gyratory shaker at 300 rev. $\min ^{-1}$.

Organisms used for the preparation of washed suspensions and extracts were grown in batch cultures (IO 1) in an impeller-agitated fermenter (Biotech, South Croydon; ro 1 capacity, air flow rate $0.41 \mathrm{~min}^{-1}$, mean generation time 9 to II h). Cyclohexane was supplied as vapour by means of a gassing bottle, containing cyclohexane, in the air line.

Measurement of growth. Growth was determined by relating the $E_{610}$ of cultures to the dry weight of organisms by a standard curve prepared using cyclohexane-grown washed suspensions. Growth yields were determined in sealed $250 \mathrm{ml}$ Monod flasks containing $50 \mathrm{ml}$ minimal medium. Carbon-limited growth was followed until there was no further increase in turbidity over a period of $12 \mathrm{~h}$, when the flasks were opened and the dry weights were measured by direct weighing of washed cells.

Preparation of washed suspensions of bacteria. Organisms were harvested by centrifuging $\left(30000 \mathrm{~g}, 20 \mathrm{~min}, 25^{\circ} \mathrm{C}\right.$ ), washed twice in $67 \mathrm{mM}-\mathrm{KH}_{2} \mathrm{PO}_{4} / \mathrm{KOH}$ buffer, $\mathrm{pH} 7 \cdot 0$, and resuspended in the same buffer.

Preparation of extracts. Washed suspensions were disrupted by one passage through a French pressure cell (Aminco, Maryland, U.S.A.; $\left.69 \mathrm{MPa}, 0^{\circ} \mathrm{C}\right)$ before centrifuging $(30000 \mathrm{~g}$, $30 \mathrm{~min}, 5^{\circ} \mathrm{C}$ ) to remove unbroken organisms and wall debris.

Measurement of oxygen uptake. Oxygen consumption was measured at $30^{\circ} \mathrm{C}$ by conventional Warburg manometry or using an oxygen electrode (Rank Bros, Bottisham, Cambridgeshire). Incubation mixtures contained (in a volume of $3 \mathrm{ml}$ ): $165 \mu \mathrm{mol} \mathrm{KH}_{2} \mathrm{PO}_{4} /$

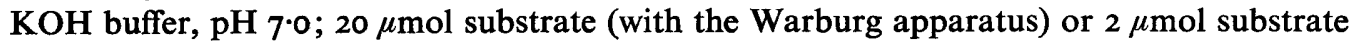
(with the oxygen electrode); and 4 to $8 \mathrm{mg}$ dry wt bacteria. Hydrocarbons were added as sonicated emulsions in water.

Enzyme assays. Cyclohexanol dehydrogenase was measured as cyclohexanone reduction by following NADPH oxidation at $340 \mathrm{~nm}$. Reaction mixtures contained (in $3 \mathrm{ml}$ ): $67 \mu \mathrm{mol}$ $\mathrm{KH}_{2} \mathrm{PO}_{4} / \mathrm{KOH}$ buffer, $\mathrm{pH} 7 \cdot 0 ; 0.5 \mu \mathrm{mol} \mathrm{NADPH} ; 2 \mu \mathrm{mol}$ cyclohexanone; and extract (0.5 to $\mathrm{I} \cdot 0 \mathrm{mg}$ protein). Cyclohexanol oxidation was followed by 2,6-dichlorophenolindophenol reduction measured at $600 \mathrm{~nm}$. Reaction mixtures contained (in $3 \mathrm{ml}$ ): $200 \mu \mathrm{mol}$ glycine/ $\mathrm{NaOH}$ buffer, $\mathrm{pH}$ 10.0; $0.3 \mu \mathrm{mol} 2$,6-dichlorophenolindophenol; $2.8 \mu \mathrm{mol} \mathrm{KCN}$; 0.5 $\mu$ mol NADP $+; 2 \mu \mathrm{mol}$ cyclohexanol; and extract ( 0.5 to $\mathrm{I} \cdot 0 \mathrm{mg}$ protein).

Cyclohexanone monooxygenase was measured as described by Norris \& Trudgill (I97I). Reaction mixtures contained (in $3 \mathrm{ml}$ ): $67 \mu \mathrm{mol} \mathrm{KH}_{2} \mathrm{PO}_{4} / \mathrm{KOH}$ buffer, $\mathrm{pH} 7.0 ; 0.5 \mu \mathrm{mol}$ $\mathrm{NADPH} ; 2 \mu \mathrm{mol}$ cyclohexanone; and extract ( 0.5 to $\mathrm{I} \cdot 0 \mathrm{mg}$ protein). 
$\epsilon$-Caprolactone hydrolase was measured by the method of Norris \& Trudgill (197I). Reaction mixtures contained (in I ml): $34 \mu \mathrm{mol} \mathrm{KH}_{2} \mathrm{PO}_{4} / \mathrm{KOH}$ buffer, $\mathrm{pH} 7 \cdot 0$; $10 \mu \mathrm{mol}$ $\epsilon$-caprolactone; and extract ( 0.1 to $0.2 \mathrm{mg}$ protein).

All enzyme assays were done at $30^{\circ} \mathrm{C}$.

Protein estimation. The protein content of extracts was determined by the method of Lowry et al. (195I), using bovine serum albumin as standard.

Gas-liquid chromatography. A coiled glass column $(\mathrm{I} \cdot 83 \mathrm{~m} \times 4 \mathrm{~mm}$ internal diam.) packed with $10 \%$ Carbowax on Chromasorb W was used in a Varian Aerograph Series I 400 gas chromatograph fitted with a flame ionization detector. Operating conditions were:

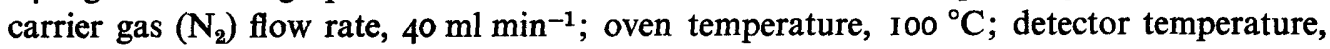
$200{ }^{\circ} \mathrm{C}$.

Electron microscopy. Freshly harvested organisms were prefixed in $0.1 \%(\mathrm{w} / \mathrm{v}) \mathrm{OsO}_{4}$ in Kellenberger buffer (Ryter \& Kellenberger, I958) before fixing overnight in $\mathrm{I} \%(\mathrm{w} / \mathrm{v})$ $\mathrm{OsO}_{4}$ in the same buffer. Fixed organisms were washed with Kellenberger buffer and embedded in agar. The agar blocks were stained for $2 \mathrm{~h}$ at room temperature with $0 . \mathrm{I} \%(\mathrm{w} / \mathrm{v})$ uranyl acetate in Kellenberger buffer. After dehydration in a graded series of ethanol/water mixtures and treatment with propylene oxide, the agar blocks were embedded in Araldite. Ultra-thin sections were cut with an LKB ultramicrotome and poststained with saturated uranyl acetate/lead citrate (Reynolds, 1963). Sections were examined in a Zeiss E.M.9 electron microscope.

Chemicals. AnalaR cyclohexane (99.8\% pure) and methylcyclohexane (98\% pure) were from BDH; NADP+ and NADPH were from Boehringer. All other chemicals were of the highest commercial quality and were obtained from BDH or Koch-Light. The commercial cyclohexanediols used were all cis-trans mixtures.

\section{RESULTS}

Culture, isolation and growth studies

Several soil and mud samples were examined for methylcyclohexane-utilizing microorganisms but only two (both from estuarine mud flats) proved positive. In both cases, cyclohexane also served as a growth substrate, but isolation of a pure culture was hindered by the production of large amounts of capsular slime. When finally obtained, pure cultures failed to grow for more than a few generations when transferred to fresh minimal media whatever the carbon source. In contrast, mixed cultures of the organism able to degrade cyclohexane together with one other bacterial isolate from the original mixed cultures grew readily on minimal media.

One strain of the organism able to utilize cyclohexane was chosen for detailed study. It was Gram-variable, non-motile, pleiomorphic and composed of branching rods. On solid media, colonies were bright-yellow, gelatinous, circular and convex. It was tentatively identified as a Nocardia. Electron micrographs of the cyclohexane-grown organism, whilst confirming the isolation of pure cultures, also revealed internal membrane structures and spherical electron-dense hydrocarbon inclusions (Fig. I $a$ ) similar to those described recently in a hydrocarbon-grown Acinetobacter (Kennedy \& Finnerty, 1975); these membranes were not present after growth on succinate (Fig. I $b$ ). The other organism in the mixed culture was not able to utilize cyclohexane directly and was a Gram-negative rod, tentatively identified as a pseudomonad.

When culture supernatant solution, obtained after growth of the pseudomonad on succinate minimal medium, was autoclaved and added to the Nocardia culture medium, 

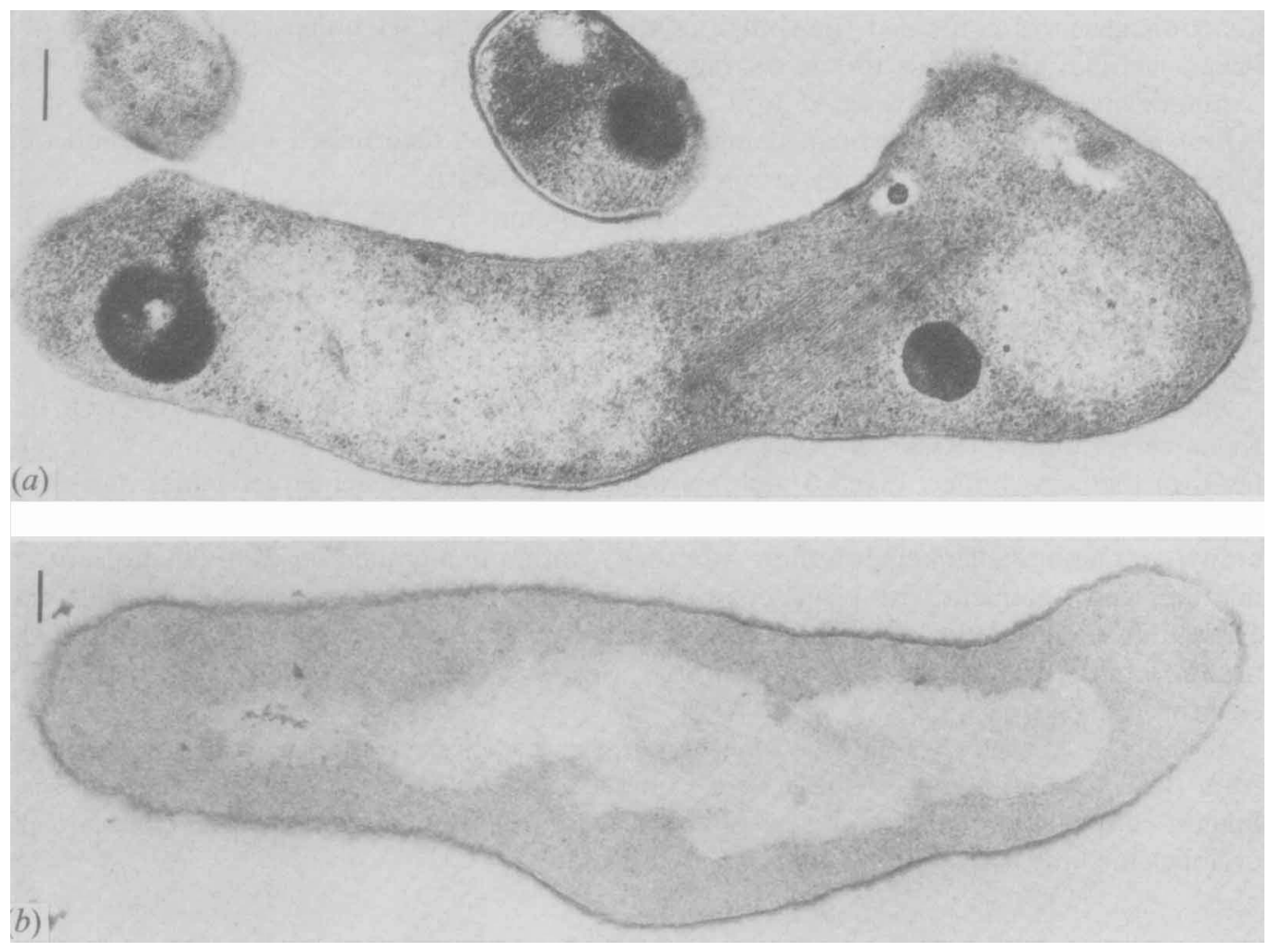

Fig. I. Sections of the Nocardia isolate after growth on (a) cyclohexane or $(b)$ succinate. Bar markers represent $0.1 \mu \mathrm{m}$.

vigorous growth of the pure culture occurred on a variety of substrates. The growth factor accumulated during growth of the pseudomonad and reached a maximum concentration just before the onset of the stationary phase. Addition of autoclaved, late-exponential phase pseudomonad culture supernatant solution to the Nocardia medium at $0.2 \%(\mathrm{v} / \mathrm{v})$ was insufficient to support growth, whilst $4 \%$ (v/v) supported vigorous growth; there was no further stimulation on adding larger proportions. Sterilized supernatant solutions from cultures of other bacteria (e.g. Escherichia coli, Klebsiella aerogenes, Bacillus subtilis) grown on minimal medium were equally effective growth promoters. Growth studies indicated that the isolate was able actively to concentrate the growth factor. The Nocardia was eventually found to be auxotrophic for biotin and autoclaved pseudomonad medium could be replaced by Io ng biotin per $\mathrm{ml}$ growth medium.

When tested for growth on cyclohexane derivatives and other potential carbon sources, the Nocardia grew readily on cyclohexanol, cyclohexanone, I,2-, I,3- and I,4-cyclohexanediols, $\epsilon$-caprolactone, ethylcyclohexane and isopropylcyclohexane, but not on cyclohexene oxide, 2-hydroxycyclohexanone, hexane, hex-I-ene, octane, oct-I-ene, heptane, decane, dodecane, hexadecane, cyclopentane, cycloheptane, adipate, glucose or glycerol.

On transfer from succinate- to cyclohexane-minimal medium, there was a variable adaptation period of 20 to $40 \mathrm{~h}$ before exponential growth commenced (mean generation time, approx. Io h). Growth substrate yield coefficients $\left(Y_{\mathrm{sUB}}\right)$ for cyclohexane and succinate were 
Table I. The effect of growth substrate on the capacity of the Nocardia isolate to oxidize cyclohexane, its analogues and possible catabolic intermediates

\begin{abstract}
Oxygen consumption rates were measured by conventional Warburg manometry or with an oxygen electrode* as described in Methods. Rates of oxygen uptake were corrected for the endogenous rate (shown in the last line).
\end{abstract}

\begin{tabular}{|c|c|c|}
\hline \multirow[b]{2}{*}{ Substrate } & \multicolumn{2}{|c|}{$\begin{array}{c}\text { Rates of oxygen uptake } \\
{\left[\mu 1 \mathrm{O}_{2} \min ^{-1}(\mathrm{mg} \text { dry wt organisms) })^{-1}\right]}\end{array}$} \\
\hline & Cyclohexane & Succinate \\
\hline Cyclohexane & 44 & 0 \\
\hline Cyclohexene & $0^{*}$ & NT \\
\hline Cyclohexanol & 40 & 0 \\
\hline Cyclohexanone & 80 & I0 \\
\hline I,2-Cyclohexanediol & 71 & 6 \\
\hline 1,3-Cyclohexanediol & $5 \mathrm{I}$ & 0 \\
\hline I,4-Cyclohexanediol & $9 \mathrm{I}$ & 0 \\
\hline I,2-Cyclohexanedione & $8^{*}$ & NT \\
\hline Cyclohexene oxide & 32 & 0 \\
\hline Methylcyclohexane & $36^{*}$ & NT \\
\hline Ethylcyclohexane & $29^{*}$ & NT \\
\hline Isopropylcyclohexane & II* & NT \\
\hline$\epsilon$-Caprolactone & 83 & 0 \\
\hline Adipate & $3 I$ & 3 \\
\hline Succinate & 47 & 80 \\
\hline None & 0.6 & 2 \\
\hline
\end{tabular}

NT, Not tested.

$59 \cdot 9$ and $5 \mathrm{I} \cdot 8 \mathrm{~g}$ dry wt (mol substrate) ${ }^{-1}$ respectively. The yield coefficients were constant over a range of substrate concentrations $\left(0.2\right.$ to $\mathrm{I} \cdot \mathrm{I} \mathrm{mg} \mathrm{ml}^{-1}$ for succinate and $0 . \mathrm{I}$ to 0.4 $\mathrm{mg} \mathrm{ml} \mathrm{m}^{-1}$ for cyclohexane).

\title{
Respiratory studies with washed suspensions
}

The ability of washed suspensions of cyclohexane-grown Nocardia to oxidize cyclohexane and some of its analogues and possible catabolic intermediates was compared with that of succinate-grown organisms (Table I). Organisms grown on cyclohexane were adapted to metabolize a variety of these compounds but organisms grown on succinate oxidized only cyclohexanone and I,2-cyclohexanediol.

\section{Enzyme activities in extracts}

Several methods for preparing extracts and of assaying activity were tried, but cyclohexane oxidation could not be detected in cyclohexane-grown bacteria. However, these extracts did contain cyclohexanol dehydrogenase, cyclohexanone monooxygenase and $\epsilon$-caprolactone hydrolase activities(Table 2). Cyclohexanol dehydrogenase and cyclohexanone monooxygenase activities were not detectable in succinate-grown organisms and the $\epsilon$-caprolactone hydrolase activity was only $3 \%$ of that in cyclohexane-grown organisms.

Cyclohexanol dehydrogenase was first detected in the Nocardia extracts while searching for cyclohexanone monooxygenase activity. Under anaerobic conditions (a control for the oxygenase activity), cyclohexanone-dependent oxidation of NADPH occurred with concomitant disappearance of cyclohexanone and formation of cyclohexanol, which were followed by gas chromatography as described in Methods. NADPH could rot be replaced 
Table 2. Activities of enzymes likely to be involved in cyclohexane catabolism in extracts of the Nocardia isolate grown on cyclohexane or succinate

Extracts were prepared and enzyme activities assayed as described in Methods and in the text.

\begin{tabular}{|c|c|c|c|}
\hline \multirow[b]{2}{*}{ Enzyme } & \multirow{2}{*}{$\begin{array}{l}\text { Growth } \\
\text { substrate ... }\end{array}$} & \multicolumn{2}{|c|}{ 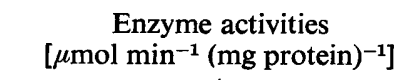 } \\
\hline & & Cyclohexane & Succinate \\
\hline $\begin{array}{l}\text { Cyclohexanol dehydrogenase } \\
\text { (cyclohexanol oxidation) }\end{array}$ & & 0.02 & ND \\
\hline $\begin{array}{l}\text { Cyclohexanol dehydrogenase } \\
\text { (reduction of cyclohexanone) }\end{array}$ & & 0.35 & ND \\
\hline Cyclohexanone monooxygenase & & 0.07 & ND \\
\hline$\epsilon$-Caprolactone hydrolase & & $12 \cdot 0$ & 0.36 \\
\hline
\end{tabular}

ND, Not detected.

by NADH. Activity could only be measured in the direction of cyclohexanol to cyclohexanone in the presence of 2,6-dichlorophenolindophenol and NADP+; the reaction rate was only $5.7 \%$ of that in the reverse direction (Table 2). The formation of cyclohexanone was confirmed by gas chromatography.

Because of the competition for NADPH between cyclohexanol dehydrogenase and cyclohexanone monooxygenase, the monooxygenase was measured with an oxygen electrode (see Methods). There was no stimulation of endogenous NADH oxidase activity by cyclohexanone, which indicates that this enzyme also is NADPH-specific.

\section{DISCUSSION}

Despite difficulties experienced by ourselves and other workers, the results described in this paper show that pure cultures of bacteria able to utilize cyclohexane as sole carbon and energy source can be isolated. As the elective culture techniques used were standard, it is difficult to identify the reason for our success. Initial election for growth on methylcyclohexane may be an important factor but it seems unlikely that cyclohexane utilization is usually associated with auxotrophy.

The internal membrane structures are similar to those in a hydrocarbon-grown Acinetobacter (Kennedy \& Finnerty, 1975) and Mycobacterium rhodochrous (Cattell, 1972). Membrane structures are well authenticated in some autotrophs and in methane-utilizing bacteria. The significance of intracytoplasmic membranes in the Nocardia and other hydrocarbon utilizers remains to be determined although we have noted that some hydrocarbon utilizing strains do not appear to contain such membranes (unpublished observations).

The respiration and enzyme studies are consistent with a catabolic route for cyclohexane involving initial oxidation to cyclohexanol followed by degradation of cyclohexanol by the route identified in Nocardia globerula and Acinetobacter (Norris \& Trudgill, 1971; Donoghue \& Trudgill, 1975); i.e. oxidation of cyclohexanol by a dehydrogenase to cyclohexanone followed by a monooxygenase-catalysed ring insertion of oxygen to form $\epsilon$-caprolactone and further breakdown of the lactone to acetate and succinate via 6-hydroxycaproate and adipate. The growth yield on cyclohexane is consistent with the involvement of two energetically-wasteful monooxygenase reactions. 
The ability of washed organisms to oxidize the cyclohexanediols, I,2-cyclohexanedione and cyclohexene oxide, does not necessarily indicate that these compounds are catabolic intermediates but may indicate a lack of specificity of the enzymes involved. Inability to observe cyclohexane oxygenase activity was not unexpected since hydrocarbon oxygenases are notoriously difficult to detect and further attempts are in hand using radioactive cyclohexane. The properties of the cyclohexanol dehydrogenase, especially the need to add an artificial electron acceptor to measure cyclohexanol oxidation, may reflect a disruption of an enzymic complex during extraction.

We are grateful to Mrs Susan Lee for carrying out the electron microscopic studies. Miss Lynne Stirling thanks the Science Research Council for a CASE Studentship.

\section{REFERENCES}

Beam, H. W. \& Perry, J. J. (1973). Co-metabolism as a factor in microbial degradation of cyclo-paraffinic hydrocarbons. Archiv für Mikrobiologie 91, 87-90.

Cattell, A. K. (1972). Studies on n-alkane utilisation by Mycobacterium rhodochrous. Ph.D. thesis, University of London.

Donoghue, N. A. \& Trudgill, P. W. (1975). The metabolism of cyclohexanol by Acinetobacter NCIB9871. European Journal of Biochemistry 60, $\mathrm{I}-7$.

IMELIK, B. (1948). Oxydation du cyclohexane par Pseudomonas aeruginosa. Comptes rendus hebdomadaire des séances de l'Académie des sciences 226, 2082-2083.

Jones, J. G. \& EDINGTON, M. A. (1968). An ecological survey of hydrocarbon-oxidizing micro-organisms. Journal of General Microbiology 52, 38I-390.

KENNEDY, R. S. \& FINNERTY, W. R. (1975). Microbial assimilation of hydrocarbons. II. Intracytoplasmic membrane induction in Acinetobacter sp. Archives of Microbiology 102, 85-90.

DE KLERK, H. \& VAN DER LINDEN, A. C. (1974). Bacterial degradation of cyclohexane. Participation of a co-oxidation reaction. Antonie van Leeuwenhoek 40, 7-15.

Lowry, O. H., Rosebrough, N. J., Farr, A. L. \& Randall, R. J. (I95I). Protein measurement with the Folin phenol reagent. Journal of Biological Chemistry 193, 265-275.

NorRIS, D. B. \& TrudGILL, P. W. (I97I). The metabolism of cyclohexanol by Nocardia globerula CLI. Biochemical Journal 121, 363-370.

OoyamA, J. \& Foster, J. W. (1965). Bacterial oxidation of cycloparaffinic hydrocarbons. Antonie van Leeuwenhoek 31, 45-65.

REYNOLDS, E. S. (1963). The use of lead citrate at high $\mathrm{pH}$ as an electron-opaque strain in electron microscopy. Journal of Cell Biology 17, 208-213.

RYTER, A. \& Kellenberger, E. (1958). Étude au microscope électronique de plasma contenant de l'acid désoxyribnucléique. I. Les nucléotides des bactéries en croissance active. Zeitschrift für Naturforschung r3B, 597-605.

Tonge, G. M. \& Higgins, I. J. (1974). Microbial metabolism of alicyclic hydrocarbons. Growth of Nocardia petroleophila (NICB9438) on methylcyclohexane. Journal of General Microbiology 81, 52I-524. 